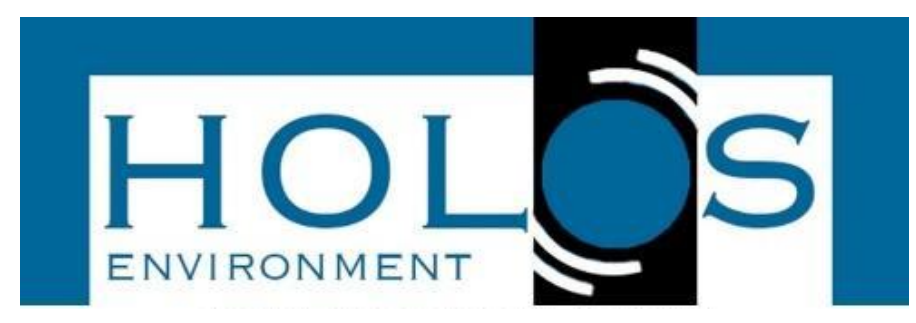

\title{
GENESIS AND PHYTODIVERSITY IN THE ENCLAVE PICO DO JABRE IN THE BRAZILIAN SEMIARID
}

\section{GÊNESE E FITODIVERSIDADE NO ENCLAVE PICO DO JABRE DO SEMIÁRIDO BRASILEIRO}

\author{
Aureliana Santos Gomes ${ }^{1}$; Ailson de Lima Marques²; Cauê Souto Vieira ${ }^{1}$; Débora \\ Coelho Moura ${ }^{1}$; Erimágna de Morais Rodrigues ${ }^{3}$; \\ Gabryelle de Farias Sousa ${ }^{1}$; Cássio Ricardo Gonçalves da Costa ${ }^{4}$
}

Artigo recebido em: 20/10/2020 e aceito para publicação em: 02/02/2021.

DOI: http://doi.org/10.14295/holos.v21i2.12428

\begin{abstract}
Among the elements that make up the landscaped areas of Caatinga, they are so-called "bogs altitude" or "moist forest enclaves," which can m have explained its genesis from the hypothesis of climate change Quaternary. This work aims to portray phytodiversity and the origin of the Pico do Jabre residual massif, located in the Northeast region, Brazilian Semi-arid region. As a result, it was found that the Pico do Jabre corresponds to a residual massif, based on the geotectonic zone of Teixeira or Pluton Teixeira, and had its origin from the differential erosion between the schist rocks of the pediplane and the granitic rocks of the massif. Its phytodiversity is distributed in altitudes where the outcrop of the plateau is home to cave species, the dimension between 900 and 1100 meters corresponds to the area of semideciduous forest montana, and Caatinga below 900 meters.
\end{abstract}

Palavras-chave: Caatinga. Landscape. Phytodiversity. Swamp of Altitude.

Resumo: Dentre os elementos que compõem as áreas paisagísticas da Caatinga, encontram-se os chamados "brejos de altitude" ou "enclaves de floresta úmida", o que pode ter explicado sua gênese a partir da hipótese de mudanças climáticas quaternárias. Este trabalho tem como objetivo retratar a fitodiversidade e a origem do maciço residual Pico do Jabre, localizado na região Nordeste, semi-árido brasileiro. Como resultado, verificou-se que o Pico do Jabre corresponde a um maciço residual, assente na zona geotectónica de Teixeira ou Pluton Teixeira, e teve a sua origem na erosão diferencial entre as rochas xistosas do pediplano e as rochas graníticas do maciço. Sua fitodiversidade se distribui em altitudes onde o afloramento do planalto abriga espécies de cavernas, a dimensão entre 900 e 1100 metros corresponde à área de floresta semidecidual montana, e Caatinga abaixo de 900 metros.

Keywords: Caatinga. Panorama. Fitodiversidade. Pântano de Altitude.

\footnotetext{
1 Universidade Federal de Campina Grande (UFCG), Campina Grande, PB. E-mails: (aurelianagomes7@gmail.com, cauesouto@hotmail.com,_debygeo@hotmail.com, gabryellesousa1205 @gmail.com)

2 Universidade Federal da Paraiba (UFPB), João Pessoa, PB. E-mails: (marques.ailsonl@gmail.com).

${ }^{3}$ Universidade Federal do Rio de Janeiro (UFRJ), Rio de Janeiro, RJ. E-mail: (erimagnarodrigues@gmail.com)

${ }^{4}$ Universidade Federal Rural do Semi-Árido (UFERSA), Mossoró, RN. E-mail: (cassioagronomoufpb@gmail.com)
} 


\section{INTRODUCTION}

The Caatinga biome corresponds to the predominant phytogeographic domain in the semi-arid region of Brazil , this one, occupies about $844,453 \mathrm{~km}^{2}$ of area extension, and comprises all the states of the Northeast of Brazil , extending to the north of Minas Gerais (BRAZIL, 2019). The Brazilian semiarid region presents characteristic factors, such as climate, vegetation, relief and soil types, inherent to these areas; with the predominantly hot and dry tropical climate, precipitation rates are scarce, with rainfall averages ranging from 300 to $1000 \mathrm{~mm}$ per year, with rainfall concentrated in a short period of time, lasting from 3 to 4 months, and high temperature levels, presenting annual thermal averages above $26^{\circ} \mathrm{C}$, which results in a high rate of evapotranspiration and the consequent water deficit in the region (QUEIROZ, 2006; ARAÚJO, 2011; COSTA, 2019).

The Caatinga part of the group Rainforest seasonally dry (FTSS) and corresponds to the most isolated nucleus of these forests neotropical (Prado, 2003), showing diverse landscapes are to intrinsic elements to the environment, send the the biome rich biodiversity, with higher rates of endemism (ARAÚJO, 2014). The Caatinga vegetation is extremely adapted to the edaphoclimatic factors, occurring deciduous and semi-deciduous vegetation species, with the presence of thorns and acuules, small leaves and roots capable of storing water as a way to ensure their survival in the dry periods ( RODAL; SAMPAIO, 2002; GIULIETTI et al. 2014).

Among the elements that make up the landscaped areas of Caatinga, they are the so - called "bogs altitude" or "humid enclaves of forest", these correspond to the topographically high areas, oriund the $s$ accidents geographical terrain and which consist of areas of refuge $s$, housing Atlantic Forest remnants and features ing themselves as exception of landscapes amid the Caatinga surrounding (TABARELLI ; SANTOS, 2004; ARAUJO, 2012) .

The genesis of these enclaves can be explained from the Quaternary climate change hypothesis (glaciation and interglaciation), which is inserted in the biogeographic theory of vegetation strongholds and fauna refuges (MARQUES et al., 2014). The theory of refuges seeks to understand the changes imposed from the climatic variations of the Quaternary (glaciation and interglaciation) that influenced the arrangement of ecological and biotic spaces, this theory had its origin from investigations carried out by different scholars such as Louis de Agassiz, as well as 
Brazilian researchers, who sought to understand the retraction and reexpansion of different vegetation domains in South America (AB 'SABER, 1992; AB' SABER, 1994).

According to Ab'Sáber (2003), these phytogeographic enclaves are characterized as patches of ecosystems belonging to other domains, such as patches of Atlantic Forest in the interior of the Caatinga. According Veloso et al (1991), these bio-geographic units may be mentioned as montane $<600 \mathrm{~m}$ submountain forests or altitude between 100 and 600 meters, forest vegetation harboring I broadleaf or seasonal. These areas point to ecological isolation, presenting different conditions in relation to the pedological, geomorphological, climatic and vegetation aspects of the surrounding Caatinga areas (GOIS et al.; 2019).

In northeastern Brazil, estimated $\mathrm{s}$ and about 43 areas of marsh, these , located in the states $d$ and Pernambuco, Ceará, Rio Grande do Norte, Paraíba and Alagoas, above the Borborema province; the state of Paraíba is home to approximately 11 of these 43 swamp areas, occurring in the cities of Araruna, Areia, Alagoa Nova, Bananeiras, Pilões, Umbuzeiro, Princesa Izabel, Monte Horebe, São José da Lagoa Tapada, São José de Piranhas and Maturéia (VASCONCELOSSOBRINHO, 1971; MARQUES et al., 2014 ; GOIS et al.; 2019).

Thus, the importance of the swamp altitude is validated, through studies that contribute to the adoption of measures that aim to guarantee the preservation of the fauna and flora of these areas, seeking to emphasize the high rates of endemism and the still unknown number of species that these environments harbor, thus contributing to the permanence of these ecosystems. In this context, the present work aims to portray the biogeography and the origin of the Pico do Jabre residual massif, located in the northeast region of the Brazilian semiarid region.

\section{MATERIAL AND METHODS}

\subsection{Characterization of the study area}

The Pico do Jabre State Park (Figure 1) located between the limits of Maturéia and Mãe D'Água , is a conservation unit founded based on State Decree No. 14,834, of October 19, 1992, initially with 500 hectares of area , subsequently expanded in 2012, now occupying 852 ha (BRASIL 2014). It is a 
residual massif and corresponds to the culmination of the state of Paraíba, with 1,197 meters of altitude, housing species of Caatinga, Atlantic Forest, Montana Semideciduous Forest and rocky vegetation, thus forming an exceptional landscape in the northeastern hinterland (AGRA et al., 2004).

The methodological procedures adopted for the study consisted of surveying and compiling bibliographic data, mapping the park area, on-site visits, carrying out botanical collections of species of angiosperms existing in the park.

Figure 1 - State Park Location Pico do Jabre

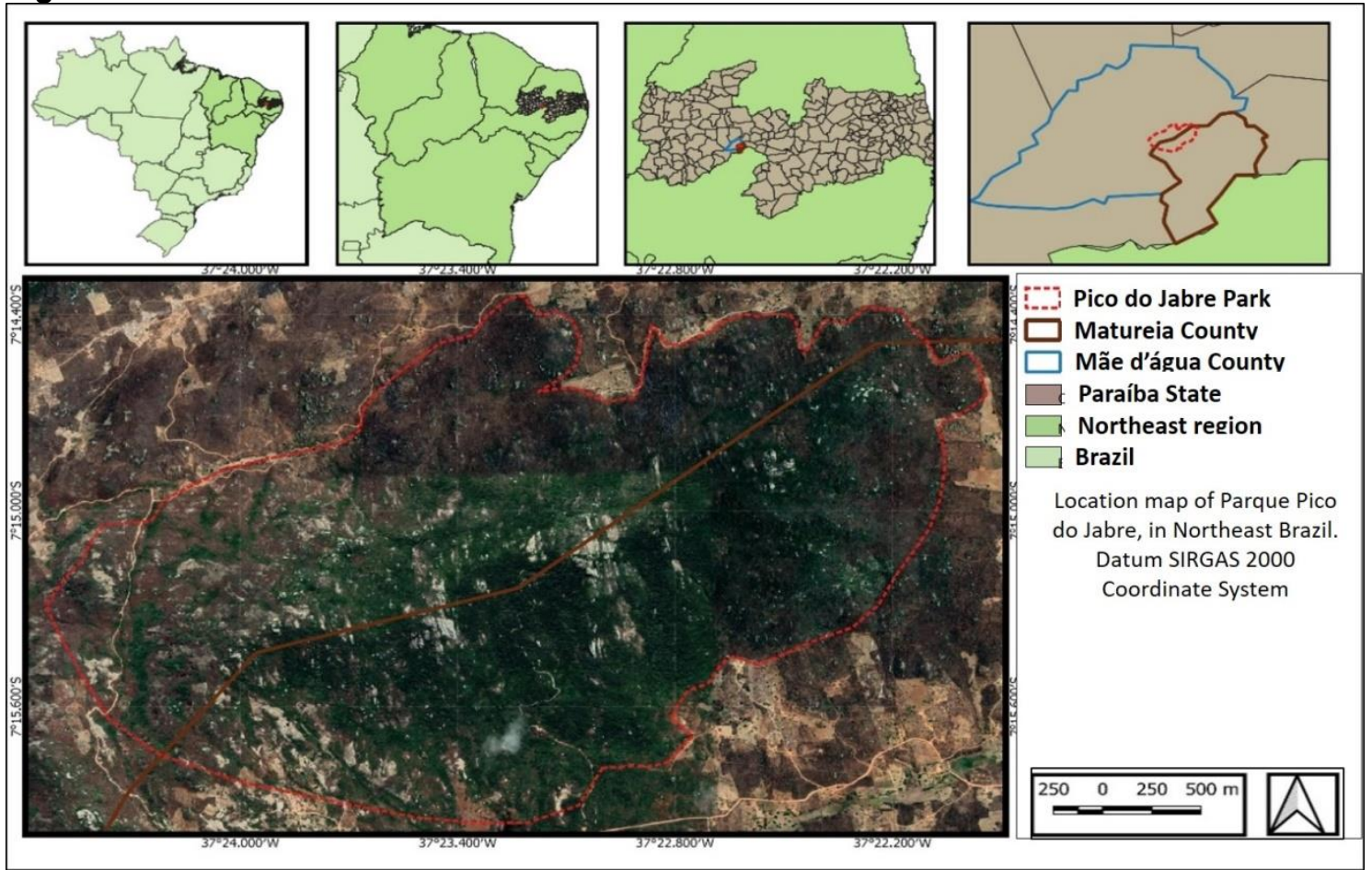

Source: Rodrigues (2020).

\section{RESULTS AND DISCUSSION}

The peak of Jabre corresponds to a residual massif, based on the geotectonic zone of Teixeira or Pluton Teixeira, and had its origin from the differential erosion between the shale rocks of the diplano foot and the granitic rocks of the massif. This solid is compreend acid by the area of Borborema, which corresponds to an extensive set of masses or blocks, spread $\mathrm{s}$ and models of by roll cha granite, migmatites, gneiss, mica slate, phyllite and quartzite, folded anticlines domus (CARVALHO, 1992). The area mass is under the geomorphology four domains (Figure 2, a,b and c) plateau Borborema, Western Borborema Escarpment, Inselbergs fields and Plain Sertaneja. 
Figure 2 - Structural Physical Map of Pico do Jabre State Park

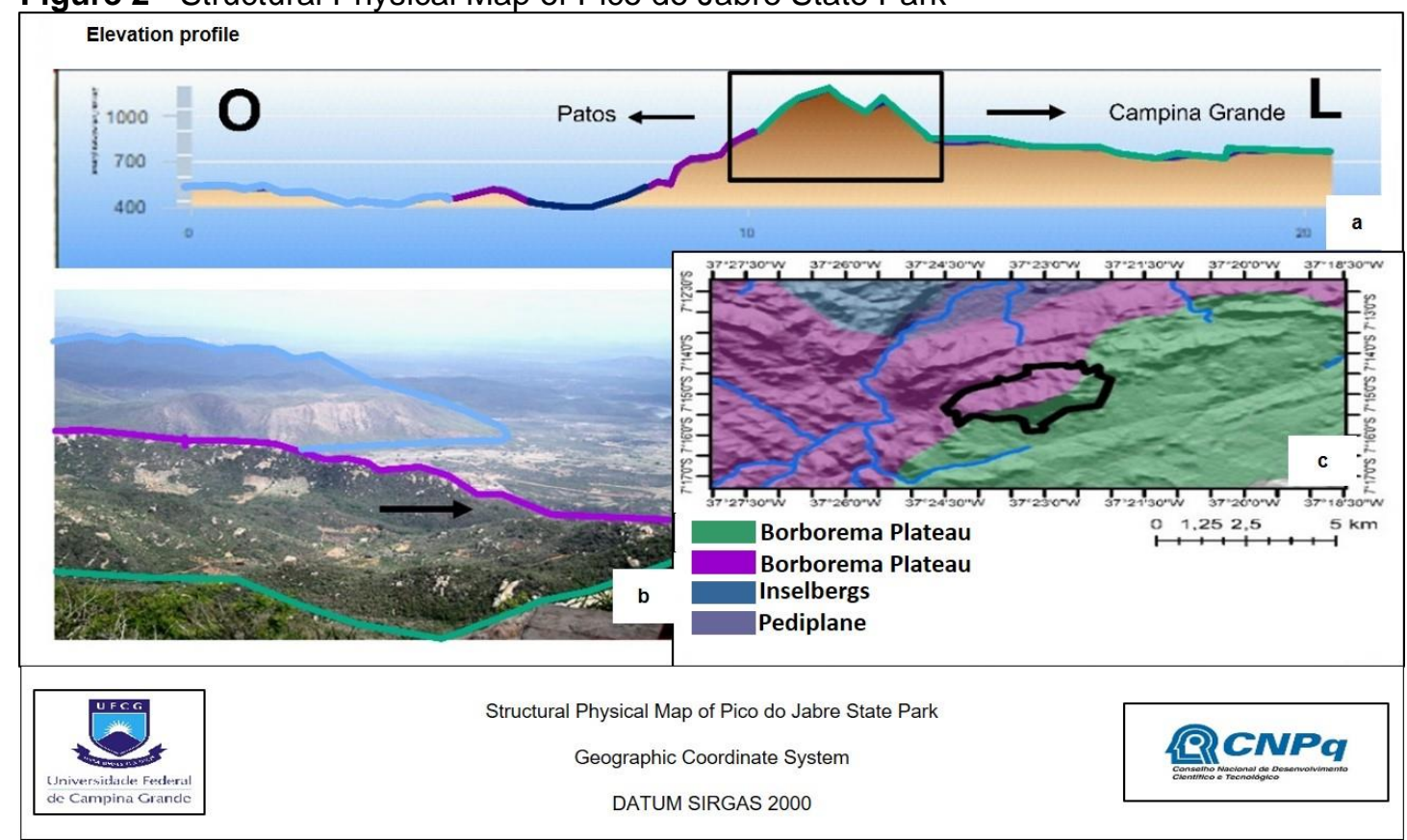

Source: Marques (2019)

The massif is part of the so-called "Morphostructure of Remobilized Massifs in the Domain of the Transversal Zone", which corresponds to the area of greatest impact from the uplift of the Borborema Plateau, resulting in the disclosure of higher summits and vigorous reliefs (CORREA et al, 2010). The landscape is composed of a sequence of isolated massifs, crests and interplanaltic depressions, a strongly undulating relief, resulting in a series of residual massifs, some of which have a significant area of outcrops (Figure 3, a and b).

Figure 3 - Panorama of the relief landscape

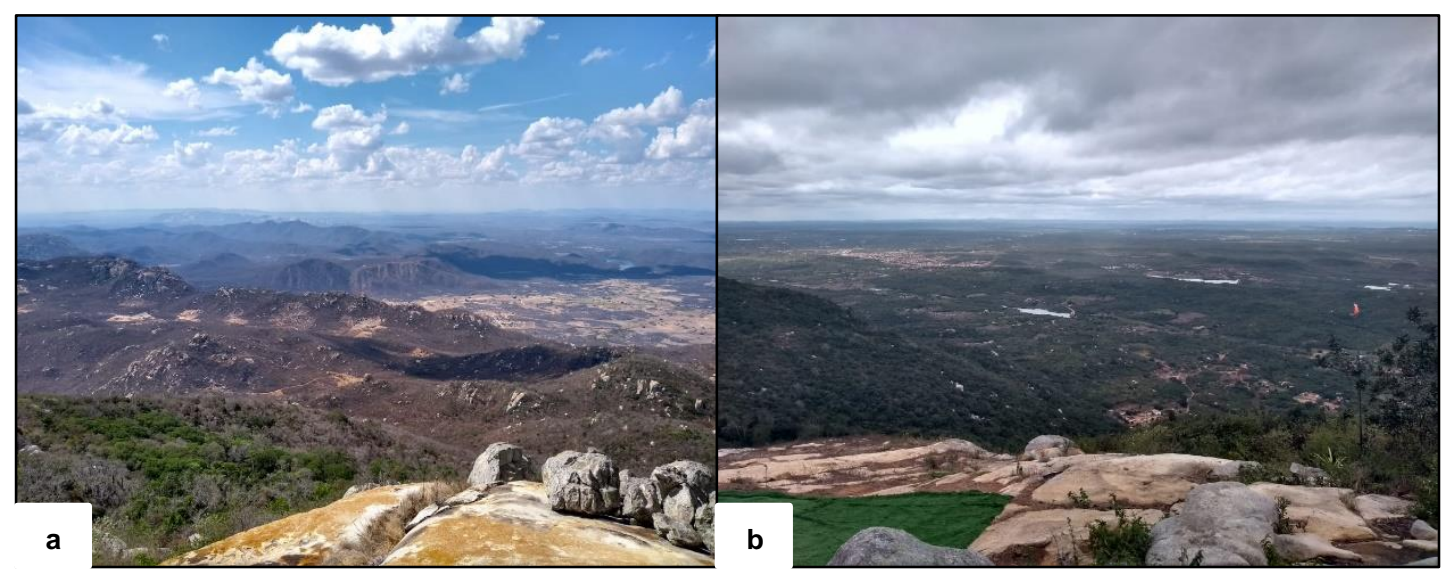

a) View of the plateau and its undulations; b) View turned to depressão sertaneja.

Source: Gomes (2019) 
The complex is formed by two ridges monoclinais which separates $\mathrm{m}$ areas and plateau plain. The ridge facing northeast has 1,197 meters of altitude and a slope of 20 to $30^{\circ}$ and the flat top and the ridge facing southwest reaches about 1,100 meters with a slope of 20 to $>30^{\circ}$ (Figure $4 \mathrm{a}$ and $\mathrm{b}$ ).

Figure 4 - A) Hypsometric profile

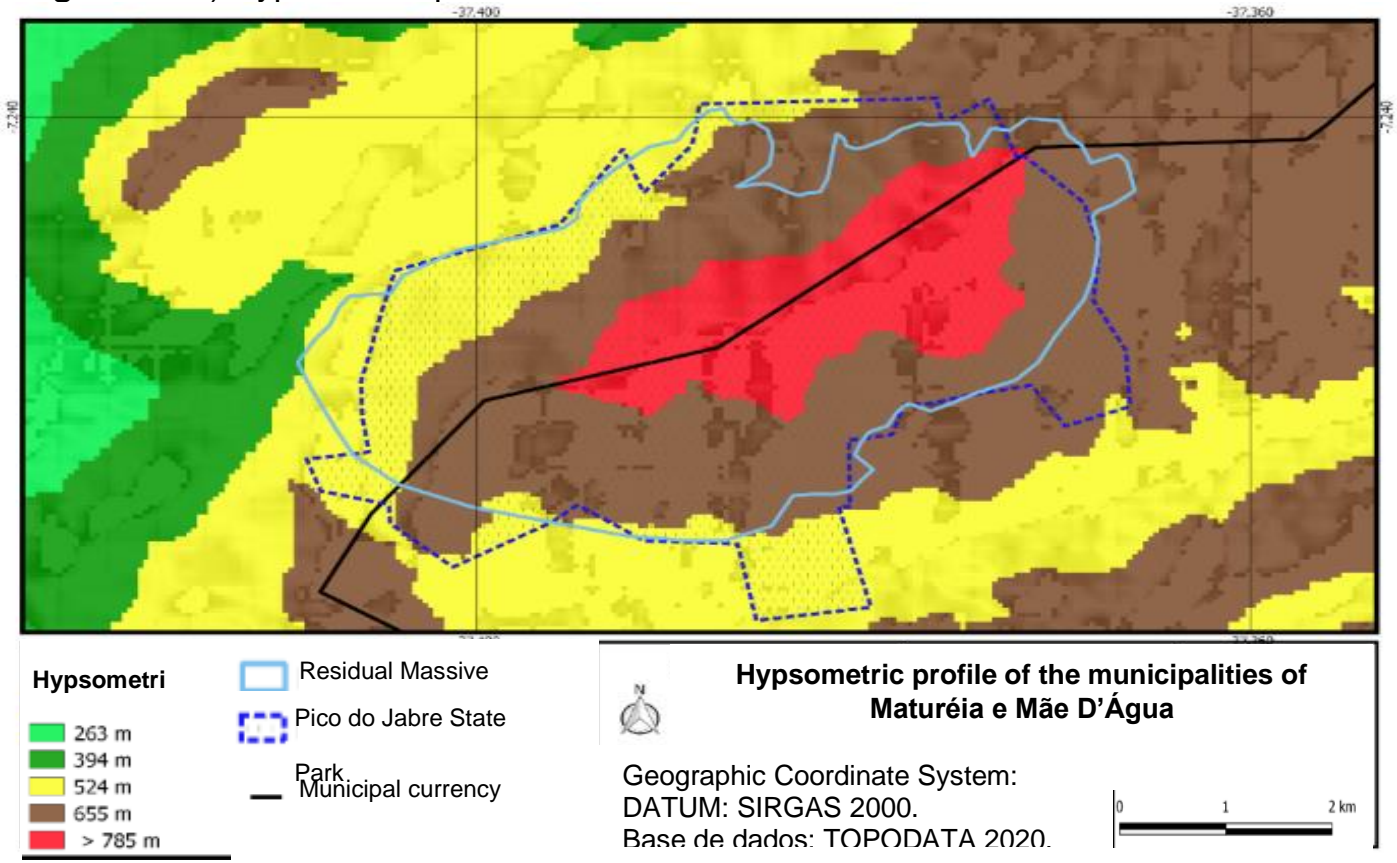

Source: Rodrigues (2020)

Figure 4 - B) Declivity of the residual massif Pico do Jabre

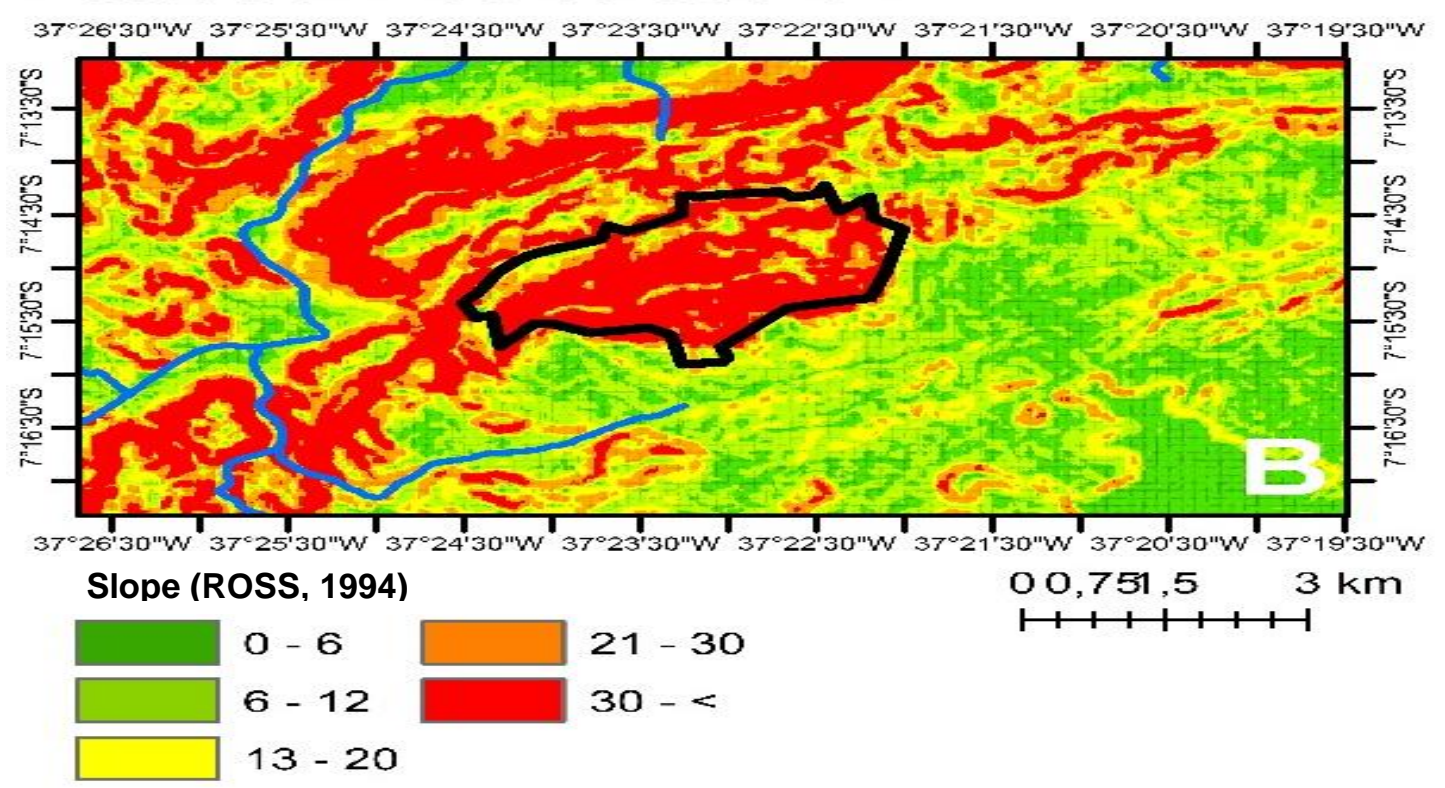

Source: Marques (2019) 
In relation to phytodiversity, a variety of vegetation species were found with records in different phytogeographic domains, such as Caatinga, Atlantic Forest and Cerrado, with different habits, from herbaceous, shrubs and sub-shrubs, ruptures of species and epiphytes, implanted in $\mathrm{s}$ at different altitudes dimensions. The Caatinga vegetation is found at elevation below 900 meters, the Semideciduous Forest vegetation is found above 900 meters and the vegetation found in the rocky outcrop of the plateau, at the top of the 1,100 meters. These data are consistentFwith the studies by Agra et al, (2004) to study the flora of the Pico do Jabre, where it points out the variation of species that vary from the plants of the Caatinga to the semideciduous Montana forest and its distribution in altitudes.

The vegetation found on the outcrop plateau, consists of rocky vegetation that fixes its roots in the substrate, also containing species of herbaceous habits and sub shrubs that fix their roots in cracks present in the rocks or in small areas with poorly developed soils. According to Benites et al.; (2003), these areas are small depressions in the outcrop itself, where there was a greater deposition of the number of material resulting from the degradation of the rock, allowing a small formation of the soil together with the accumulation of organic matter, enabling the fixation of the roots. According to Pereira et al.; (2019), the physiographic characteristics of these rocky environments contribute to an adaptive process of vegetation. Among the species located on the outcrop plateau, individuals from the families were identified: Cactaceae, Bromeliaceae, Fabaceae (Figure 5 a, b and c) among other typical outcrop species.

In altimetry, it measures between 900 and 1,100 meters, dominated by forest and semi-seasonal species, Atlantic Forest and some species of Cerrado. This area presents deep red-yellow argisol soil formation, where it was possible to see depressions with water accumulation on the slopes in its most flattened areas, which corroborates with a greater diversity of large tree species and humid environment. According to Ferraz et al. (1998), this is due to the relative humidity, the greater accumulation of precipitation and the more fertile soils present in these areas. Species of the families Arecaceae, Malvaceae and epiphytic species of Broméliaceae were found (Figure $6 \mathrm{a}, \mathrm{b}$ and $\mathrm{c}$ ). 
Figure 5 - Panorama of rock vegetation on the outcrop plateau

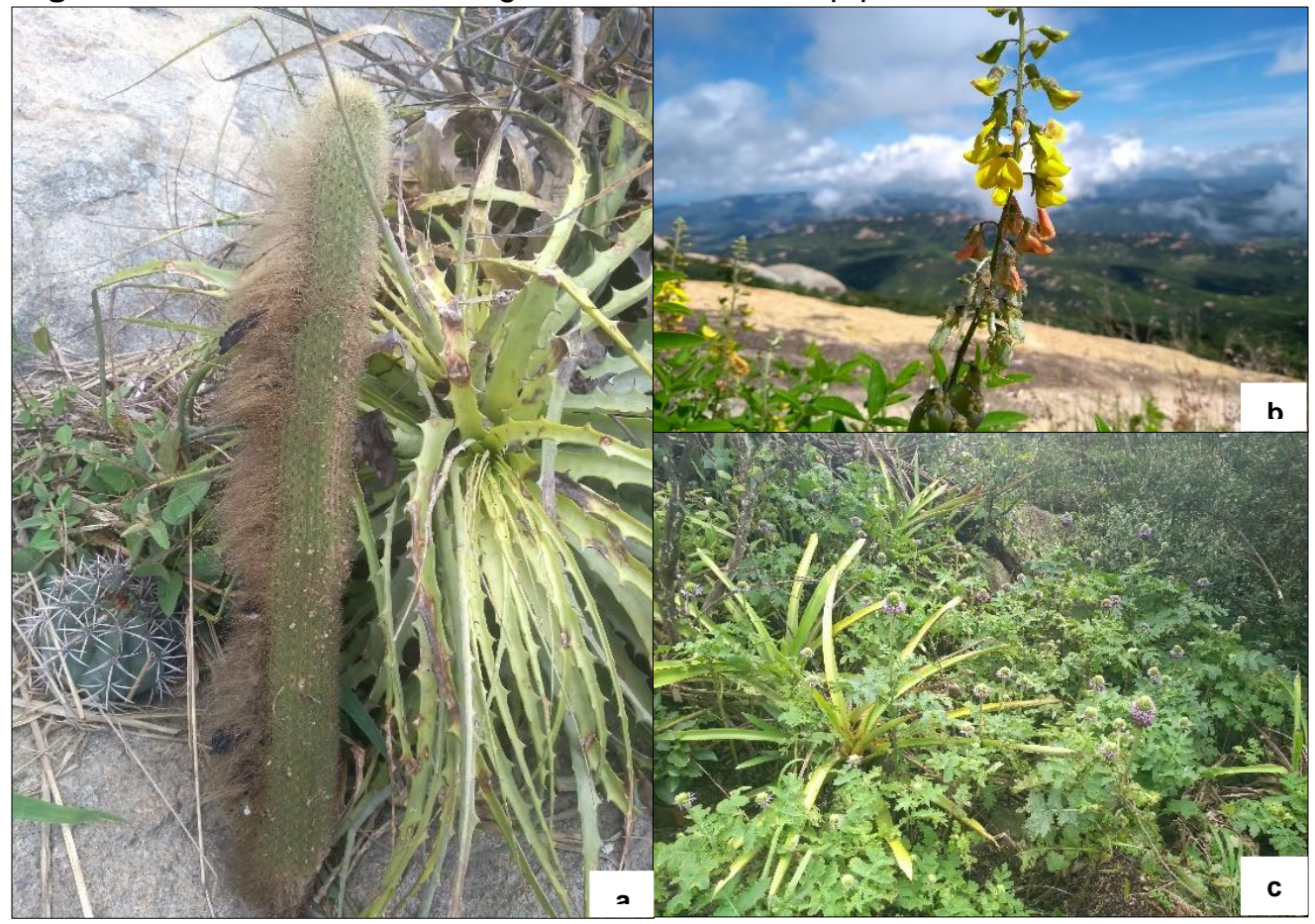

a) Cactaceae and Broméliaceae attached to the ao substrate; b) Fabaceae in the fissure of the rock; c) Asteraceae e Bromeliaceae in an area with little soil formation. Source: GOMES, A. S. 2019.

Figura 6 - Panorama of seasonal semideciduous forest vegetation

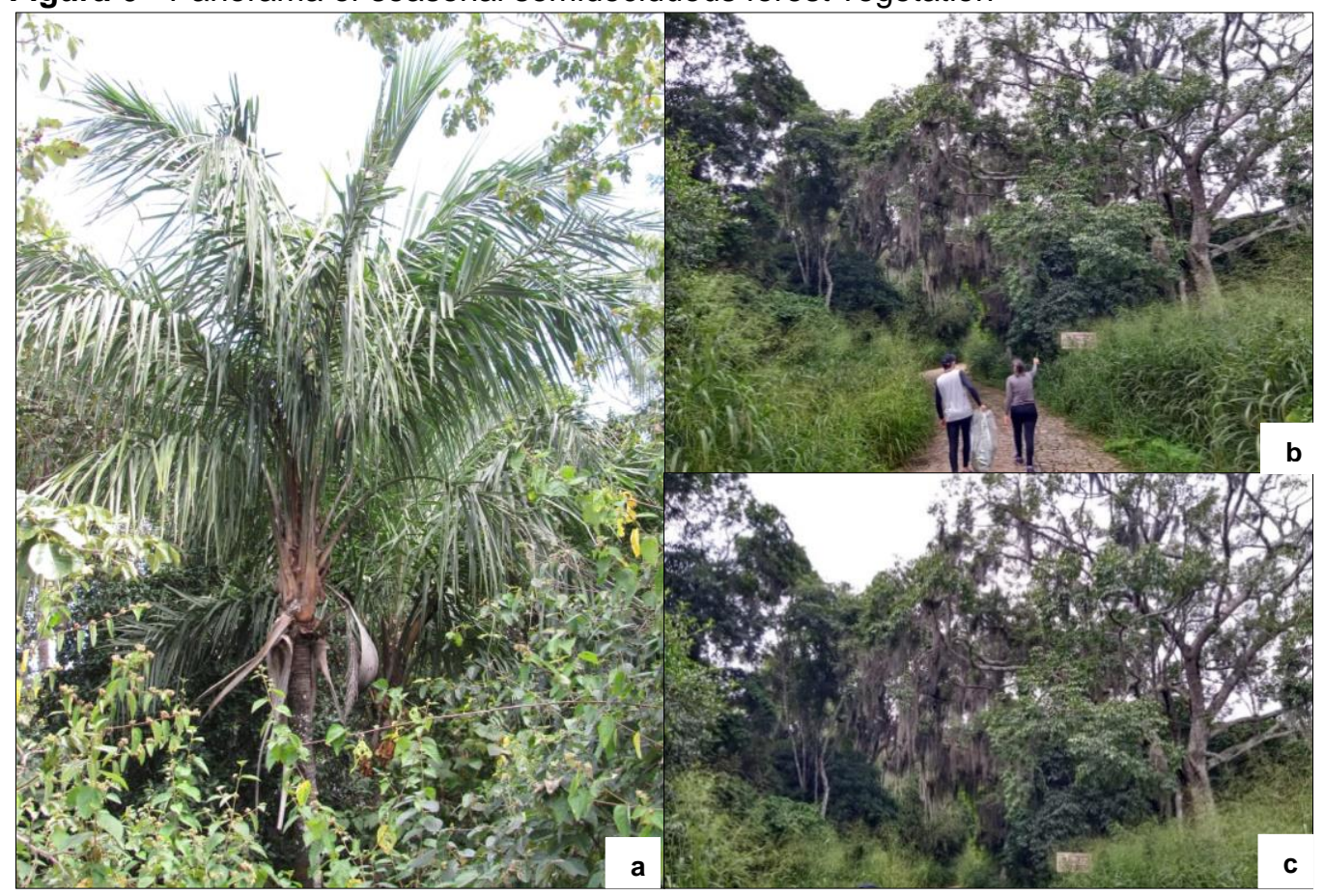

a) Arecaceae; b) Malvaceae; c) Bromeliácea.

Source: Gomes (2019) 
In altimetric levels below 900 meters, predominantly Caatinga vegetation occurs with species of Euphorbiaceae, Verbenaceae, Centrosema brasilianum, Asteraceae and Fabaceae (Figure 7 a, b, c, d and e) among other species typical of the domain. The Caatinga vegetation is composed of microfilae, succulent species, with the presence of thorns, capable of storing water in its roots, in order to guarantee survival in periods of drought (PRADO, 2003; FERNANDES; QUEIROZ, 2018). According to (GIULIETTI et al., 2006; GIULIETTI et al., 2002), the Caatinga presents a diversity of landscapes with different topographic levels and edaphic multiplicity, rich in biological diversity and endemism, presenting about 318 endemic species.

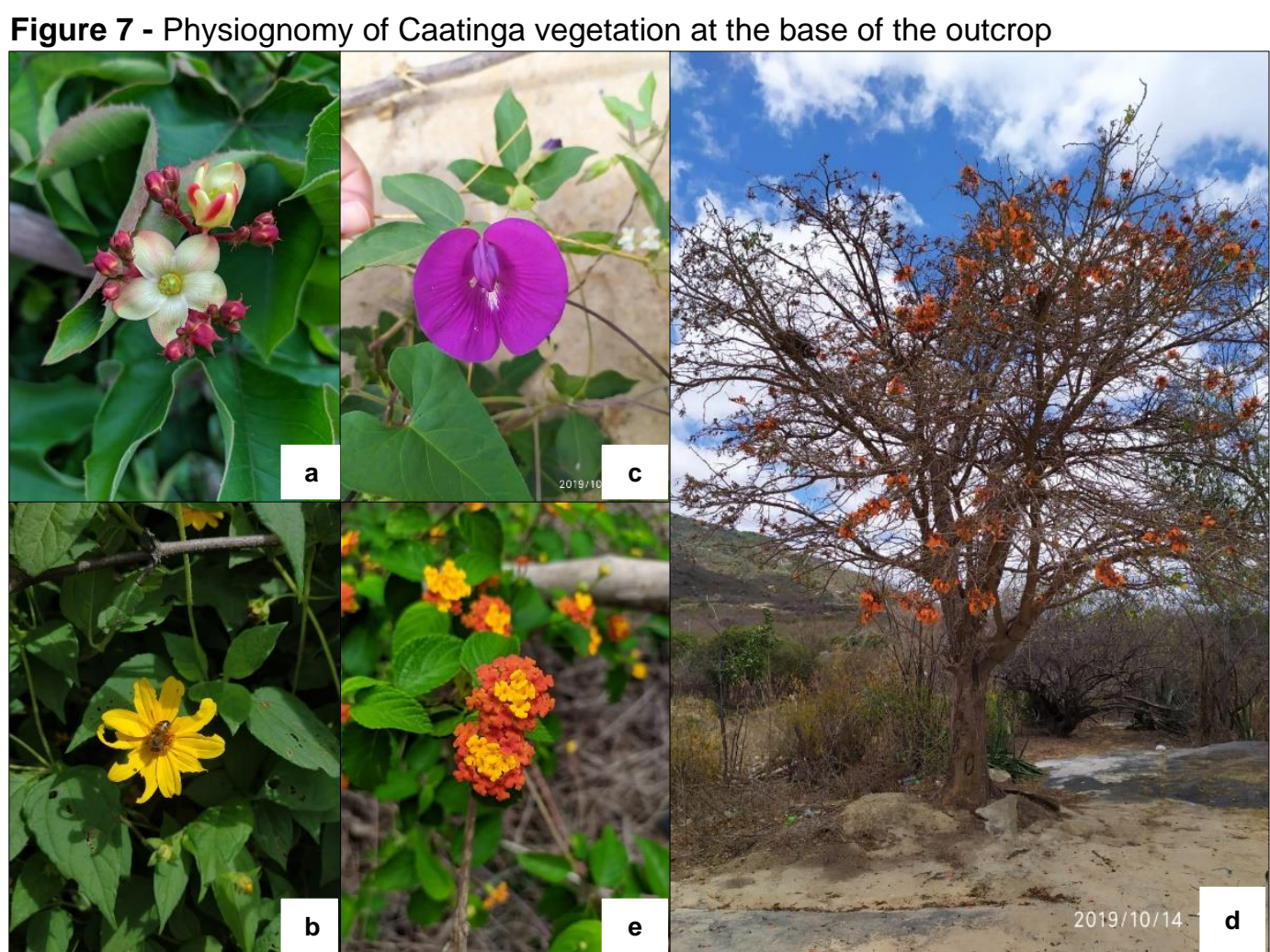

a) Euphorbiaceae, b) Asteraceae, c) Fabaceae, d) Fabaceae and e) Verbenaceae.

Source: Gomes (2019).

\section{CONCLUSION}

When analyzing the genesis and phytodiversity of the Pico do Jabre, it stands out that it corresponds to a residual mass that makes up the Morpho-structure of the Remobilized Massifs of the Transversal Zone, with an altitude of 1,197 meters, resulting from a differential erosive process of the schist rocks of the pediplane and granitic rocks of the massif. The vegetation that this resurgence presents is distributed in an altitudinal gradient of the Caatinga, Semideciduous Forest and Rupeste 
vegetation, also harboring closed species in its plant composition. As they present an area of plant diversity in the middle of the caatinga, the highland marshes represent an important area for the study of biogeographic dynamics, making it necessary for their conservation, which makes it possible to preserve species that are possibly threatened with extinction. In this context, the Pico do Jabre State Park represents an important ecosystem for biodiversity, and it is necessary for its preservation to maintain the local biota.

\section{REFERENCES}

AB'SABER, N. A. The theory of refuges: origin and meaning. In: Proceedings of the 2 nd National Congress on Native Essences. São Paulo: Instituto Florestal, p. 29-34, 1992.

AB'SABER, N. A. Forest strongholds, wildlife refuges and men's refuges. Journal of Archeology, v. 8(2), p. 1-35, 1994.

AB'SABER. N. A. The domains of nature in Brazil: landscape potential. 1st edition. Sao Paulo. 2003.

AGRA, M. F.; BARBOSA, M. R. DE V.; STEVENS, W. D. Preliminary Floristic Survey of the Pico do Jabre, Paraíba, Brazil. In: PORTO, K. C.; CABRAL, J. P.; TABARELLI, M. (Eds.). Altitude swamps of Pernambuco and Paraíba: natural history, ecology and conservation. Brasília-DF: Ministry of the Environment. p.123-137, 2004.

ARAÚJO, S. M S. Time, Space and Biogeography. In: RODRIGUES, A. F.; SILVA, E. \& AGUIAR, J. O. Nature and culture in the domains of clio: history, environment and ethnic issues. EDUFCG, p. 155-176, 2012.

ARAUJO, D. Climbers of the caatinga biome. In: VILLAGRA B. L. P., MELO, M. M. R. F.; ROMANIUC-NETO, S. BARBOS, A. L. M. (Org.) Diversity and conservation: contribution to the restoration of Brazilian ecosystems. São Paulo: I MESP, p. 33-57, 2014.

ARAUJO, S. M. S. The semi-arid region of Northeast Brazil: environmental issues and possibilities for sustainable use of resources. Rios Eletrônica - Scientific Journal of FASETE, v. 5, n. 5, p. 89-98, 2011.

BENITES, V. M. Soils and vegetation in the high altitude rock complexes of Mantiqueira and Espinhaço. Forest and Environment, v. 10, n. 1, p. 76-85, 2003.

BRAZIL. Environment Administration Superintendence. Protected Areas: Conservation Units, v. 105, 2014.

BRAZIL. Caatinga: one of the least protected biomes in Brazil. Joaquim Nabuco - FUNDAJ Foundation, 2019.

CARVALHO, M. G. R. F. State of Paraíba: geomorphological classification. University Publisher, João Pessoa, 1992.

CORRÊA, A. C. B.; TAVARES, B. A. C.; MONTEIRO, K. A.; CAVALCANTI, L. C. S.; LIRA, D. R. Geomorphology and morphostructure of the Borborema Plateau. Revista do Instituto 
Geológico, São Paulo, v. 31, n. 31, p. 35-52, 2010. https://doi.org/10.5935/0100929X.20100003

COSTA, C. R. G.; FRAGA, V. S.; LAMBAIS, G. R.; SOARES, K.O.; SUDDARTH, S.R.P.; MEDEIROS S.S. 2019. Chemical and Physical Quality of the Entisol in a Natural Regeneration Area in the Semiarid Region of Paraiba. Journal Of Experimental Agriculture International, $v$. 35, n. 2, p. 1-7. https://doi.org/10.9734/jeai/2019/v35i230202

CUNHA, M. C. L.; JÚNIOR, M. C. S. Tree communities in the seasonal semideciduous forest Montana do Pico do Jabre, Paraíba. Forest Science, v. 28, n. 4, p. 1365-1380, 2018. https://doi.org/10.5902/1980509835046

FERRAZ, E. M. N. Floristic composition in patches of vegetation of caatinga and swamp of altitude in the region of Vale do Pajeú, Pernambuco. Brazilian Journal of Botany, v. 21, n. 1, p. 7-15, 1998.

FERNANDES, M. F.; QUEIROZ, L. P. Vegetation and flora of the Caatinga. Science and culture, v. 70, n. 4, p. 51-56, 2018. https://doi.org/10.21800/2317-66602018000400014

GIULIETTI, A. M.; HARLEY, R. M.; QUEIROZ, L. P.; BARBOSA, M. R. V.; BOCAGE-NETA, A. L.; FIGUEIREDO, M. A. Species endemic to the Caatinga. In: SAMPAIO, E. V S. B.; GIULIETTI, A. M.; VIRGÍNIO, J.; GAMARRA-ROJAS, C. F. L. (Ed.). Vegetation and flora of the Caatinga. Recife: APNE, p. 103-118, 2002.

GIULIETTI, A. M. Diagnosis of native vegetation in the caatinga biome. In: SILVA, J. M. C.; TABARELLI, M.; FONSECA, M. T.; LINS, L. V. (Org.). Caatinga biodiversity: priority areas and actions for conservation. Brasília, DF: Ministry of the Environment: Federal University of Pernambuco, p. 48-78, 2003.

GIULIETTI, A. M.; CONCEIÇÃO, A.; QUEIROZ, L. P. Diversity and characterization of phanerogams in the Brazilian semi-arid region. Recife: Millennium Institute of the SemiArid Region. p. 488, 2006.

GOIS, L. S S.; CORRÊA, A. C. B.; MONTEIRO, K. A. Integrated Analysis of Brejos de Altitude do Nordeste do Brasil from Physiographic Attributes. Open Space, v. 9, n. 2, p. 77-98, 2019. https://doi.org/10.36403/espacoaberto.2019.28357

GOIS, L. S. S. A review of altitude swamps in NE Brazil: In: PINHEIRO, L. S.; GORAYEB, A. (Org.). Fortaleza: Editora UFC. 2019.

MARQUES, A. L., SILVA, J. B., SILVA, D. G. Wetlands of the Semi-Arid: A Study on the Altitude Brejo de Areia-PB. GeoThemes, v. 4, n. 2, p. 17-31, 2014.

PEREIRA, T. M. S.; MOURA, D. C.; MELO, J.; LIMA, S. J. A. Riqueza and floristic diversity in rocky outcrops in the city of Esperança- Paraiba. Geographic ACTA, v. 13, n. 31, p. 90-103, 2019.

PRADO, D. E. The caatingas of South America. In: LEAL, I. R.; TABARELLI, M.; SILVA, J. M. C. (eds.). Ecology and conservation of the Caatinga. University of UFPE, Recife. p.3-74, 2003.

QUEIROZ, L. P. The Brazilian Caatinga: Phytogeographical patterns inferred from distribution data of the Leguminosae. In: PENNINGTON, R. T.; RATTER, J. A. (eds.) Neotropical savannas and seasonally dry forests plant diversity, biogeography, and 


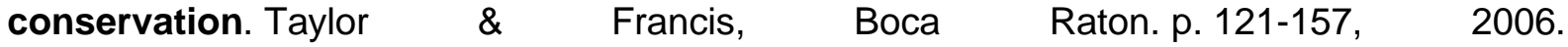
https://doi.org/10.1201/9781420004496-6

RODAL, M. J. N.; SAMPAIO, E. V. S. B. The vegetation of the caatinga biome. In: SAMPAIO, E. V. S. B. (Org.). Vegetation and Flora of the Caatinga. Recife: Associação Plantas do Nordeste - APNE; Northeastern Plant Information Center - CNIP, p. 11-24. 2002.

TABARELLI, M.; SANTOS, A. M. M. A brief description of the natural history of the northeastern swamps. In PORTO, K. C.; CABRAL, J. J. P.; TABARELLI, M (Org) Altitude Brejos in Pernambuco and Paraíba: Natural History, Ecology and Conservation. Brasília, DF: Ministry of the Environment, p. 17-24, 2004.

VASCONCELOS SOBRINHO, J. The natural regions of the Northeast, the environment and civilization. Recife: CONDEPE, p. 441, 1971.

VELOSO, H. P.; RANGEL-FILHO, A. L. R.; LIMA, J. C. A. Classification of Brazilian vegetation adapted to a universal system. Rio de Janeiro, IBGE. Department of Natural Resources and Environmental Studies. 1991. 